\title{
Pulmonary embolism caused by thrombin-based haemostatic matrix
}

\author{
Ala-Eddin S Sagar, ${ }^{1}$ Erik Vakil, ${ }^{2}$ Carlos A Jimenez, ${ }^{2}$ Reeba Mathew ${ }^{1}$
}

'Pulmonary, Critical Care and Sleep Medicine, University of Texas Health Science Center at Houston, Houston, Texas, USA ${ }^{2}$ Pulmonary Medicine, University of Texas MD Anderson Cancer Center, Houston, Texas, USA

\section{Correspondence to}

Dr Carlos A Jimenez,

cajimenez@mdanderson.org

Accepted 27 November 2017

\section{DESCRIPTION}

A 38-year-old woman underwent an outpatient L5/S1 discectomy. The procedure was complicated by intraoperative bleeding, and haemostasis was achieved using a thrombin-based haemostatic matrix (TBHM). She presented to our facility on postoperative day 5 with left-sided chest pain and dyspnoea. CT pulmonary angiography (CTPA) showed a heterogeneous filling defect with mixed attenuation and a 'pseudoair pattern' in the left main pulmonary artery (figure 1). Duplex ultrasound of the upper and lower extremities was negative for venous thrombus. An echocardiogram was normal. Pulmonary angiography showed occlusion of the basal branches of the left pulmonary artery (figure 2). Therapeutic anticoagulation with unfractionated heparin was started, and the patient was discharged home on warfarin. Repeat CT angiography 6 months later revealed no filling defect in the pulmonary arteries.

TBHM is a mixture of gelatin granules and human or bovine-derived thrombin. It can be deployed intraoperatively via a syringe over the haemorrhagic area. Haemostasis is achieved by activating factors V, VIII and XIII, and inducing platelet aggregation. TBHM has been implicated in pulmonary embolism by accidental injection into veins or through gradual uptake of the matrix into the venous system. ${ }^{1}$ A 'pseudoair pattern' on CTPA is thought to be highly suggestive of TBHM embolism. ${ }^{2}$ While the imaging pattern may also represent air that entered the vessel at the time of injury, the initial imaging was 5 days after the surgery, and the pulmonary angiogram was a day afterwards. Air would typically show some degree of resolution given the time span since the surgery.

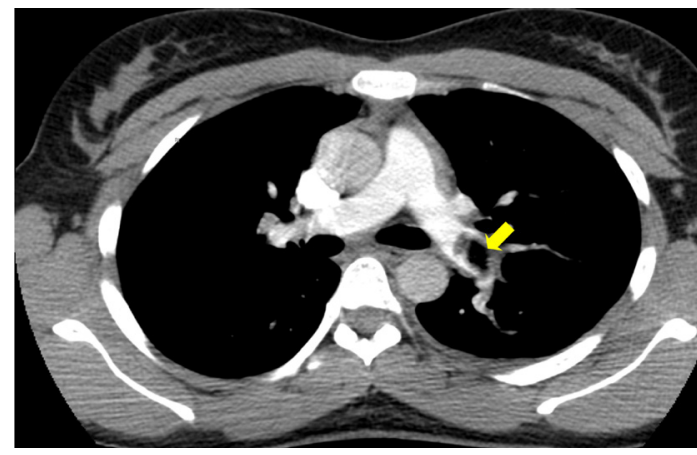

Figure $1 \mathrm{CT}$ chest with contrast demonstrating the 'pseudoair' filling defect (arrow) in the left main pulmonary artery.

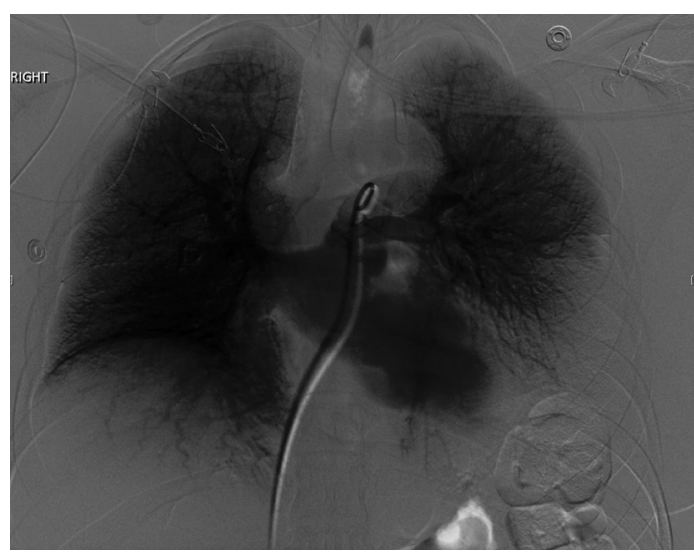

Figure 2 Near total occlusion of the left lower pulmonary artery with no perfusion of the left lower lobe.

\section{Learning points}

Thrombin-based haemostatic matrix (TBHM) has been implicated in pulmonary embolism by accidental injection into veins or through gradual uptake of the matrix into the venous system.

- A 'pseudoair pattern' on CT pulmonary angiography is highly suggestive of TBHM embolism

There are limited data on treatment of patients with pulmonary embolism related to TBHM, although a similar case described successful treatment with anticoagulation alone. ${ }^{3}$ Documented resolution of pulmonary embolism caused by TBHM following treatment with anticoagulation has not been described in the literature before. Our case suggests that anticoagulation may be an appropriate option when managing these patients.

Contributors ASS, EV, CAJ and RM: conception and design, acquisition of radiological data, drafting the article, critical revision of intellectual content and final approval of the version to be published. The authors (A-ESS, EV, CAJ and RM) declare that 'all the authorship are aware of and approve the manuscript being submitted to this journal'.

Competing interests None declared.

Patient consent Obtained.

Provenance and peer review Not commissioned; externally peer reviewed.

Author note The authors (ASS, EV, CAJ and RM) certify that this is an original research work, which has not been published anywhere else in any form and does not involve any sources of financial support from any source whatsoever. 
(c) BMJ Publishing Group Ltd (unless otherwise stated in the text of the article) 2017. All rights reserved. No commercial use is permitted unless otherwise expressly granted.

\section{REFERENCES}

1 Ferschl MB, Rollins MD. Thromboemboli, acute right heart failure and disseminated intravascular coagulation after intraoperative application of a topical hemostatic matrix. Anesth Analg 2009;108:434-6.
2 Learned KO, Mohan S, Hyder IZ, et al. Imaging features of a gelatinthrombin matrix hemostatic agent in the intracranial surgical bed: a unique space-occupying pseudomass. AJNR Am J Neuroradiol 2014:35:686-90.

3 Wei Z, Elder BD, Goodwin CR, et al. Bilateral pulmonary emboli associated with intraoperative use of thrombin-based hemostatic matrix following lumbar spine interbody fusion. J Clin Neurosci 2015;22:1502-5.

Copyright 2017 BMJ Publishing Group. All rights reserved. For permission to reuse any of this content visit

http://group.bmj.com/group/rights-licensing/permissions.

BMJ Case Report Fellows may re-use this article for personal use and teaching without any further permission.

Become a Fellow of BMJ Case Reports today and you can:

- Submit as many cases as you like

- Enjoy fast sympathetic peer review and rapid publication of accepted articles

Access all the published articles

- Re-use any of the published material for personal use and teaching without further permission

For information on Institutional Fellowships contact consortiasales@bmjgroup.com

Visit casereports.bmj.com for more articles like this and to become a Fellow 